\title{
Bir Olağanüstü Çocuk Figürünün Etrafında: Recaizade Mahmut Ekrem'in Nijad Tipolojisi
}

\author{
DR. ÖĞR. ÜYESİ BİLGİN GÜNGÖR*
}

Öz

Tanzimat döneminin ve Türk romantizminin öncü isimlerinden olan, edebî eserlerinden çok edebiyat kuramına dönük olarak ortaya koyduğu eserleriyle bilinen ve bu nedenle çağdaşları tarafından "üstad" kabul edilen Recaizade Mahmut Ekrem, 15 yaşında kaybettiği oğlu Nijad Ekrem'i sıklıkla şiirlerine ve mensur şiirlerine konu edinmiştir. Bu eserlerde Nijad, okurun karşısına olağanüstü bir figür olarak çıkar: Bir filozof gibi derin düşüncelere yönelir; en ince zevkleri bulunan sanatçılarla hemen hemen aynı estetik duyarlılığ taşır; milli ve dini hassasiyetleri son derece gelişmiştir; olgun insanlara yakışır şekilde sayg1 ve nezaket sahibidir. İşte bu çalışmada, söz konusu özellikler ekseninde, Nijad'ın olağanüstü bir figür olarak tipleştirilmesinin üzerinde durulacak ve daha çok esermerkezli bir okuma perspektifinden hareketle Ekrem'in Tefekkür ve Nijad Ekrem adlı eserlerinde beliren tipolojik yönelim üzerine bir yorumsamaya gidilecektir.

Anahtar sözcükler: Nijad Ekrem, tip, Tanzimat şiiri, çocuk, olağanüstülük.

\section{AROUND AN EXTRAORDINARY CHILD FIGURE: RECAIZADE MAHMUT EKREM'S NIJAD TYPOLOGY}

\section{Abstract}

Recaizade Mahmut Ekrem, who is one of the leading names of Tanzimat period and Turkish romantism, is known for his opinions about literary theories rather than literary works and hence, he is recognized by his contemporaries as "master". He often brought his son Nijad Ekrem, whom he lost at the age of 15, into his poems and prose-poems. In these works, Nijad appears as an extraordinary figüre in the face of the reader: He, like a philosopher, goes to deep thoughts; has almost the same aesthetic sensitivity as artists who have the finest pleasures; his national and religious sensitivities improved greatly, and he has respect and grace of mature people.

This work will focus on the characterization of Nijad as an extraordinary figure in the context of mentioned features, and an interpretation will be made on the typological

\footnotetext{
* Çanakkale Onsekiz Mart Üniversitesi Fen Edebiyat Fakültesi TDE Bölümü, orcid.org/0000-0001-7702-1668, bilgingungor@yandex.com. Gönderim tarihi: 24.01.2018～Kabul tarihi: 03.03.2018
} 
orientation in Ekrem's works Tefekkür and Nijad Ekrem by means of a more work-centered reading perspective.

Keywords: Nijad Ekrem, type, Tanzimat poem, child, miraculousness.

\section{GíRiş}

debiyat tarihlerinde Tanzimat edebiyatı ikinci dönem öncülerinden birisi
olarak kabul edilen, fakat İsmail Parlatır'ın da belirttiği gibi "sanatçı"
yönünden çok "kuramcı" yönüyle öne çıkan, bu nedenle de "üstad" olarak vasıflandırılan (2012: 9), özellikle de "sanatın maksadı güzelliktir" (RME2014b: 134) yargısından da anlaşılacağı üzere edebiyatın işlevselliğini salt estetik bir mahiyette kavrayarak ve bu kavrayışı hem kendi dönemindeki hem de sonraki kuşaklara yayarak modern sanat duyarlılığını ${ }^{1}$ Türk edebiyatı özelinde tesis eden Recaizade Mahmud Ekrem'in eserlerinde tipolojisi şüphesiz en net çizilen figür, 15 yaşında ölen² oğlu Nijad Ekrem'dir. Ekrem, Nijad'ın doğumundan sonra pek çok şiirinin estetik düzlemine bir şekilde onu dâhil eder, ona olan sevgisini ortaya koymaktan çekinmez. Nijad, birazdan da görüleceği gibi, 1910'da yayımlanan ve Ahmet Hamdi Tanpınar tarafından "Filhakika ne Rübab, ne de Mâi ve Siyah bu mektebin iki şaheseri olmalarına rağmen Servet-i Fünun edebiyat davranışını bize onun kadar çıplak vermezler" sözleriyle Servet-i Fünûn estetiği içerisinde konumlandırılan (Tanpınar 2007: 431) Nijad Ekrem'de tipolojik açıdan en küçük ayrıntılarıyla birlikte ortaya konulur. Fakat, söz konusu tipolojiye geçmeden evvel, konuyla ilgili açıklayıcı bir mahiyet arz edeceği için, öncelikle, Ekrem ile oğlu arasındaki ilişkinin ve bunun eserlerine yansıyış biçiminin ele alınması gerekmektedir.

Ekrem, kendisi gibi hastalıklı ve hassas bir bünyeye sahip olan Nijad'1 çok sever ve ona neredeyse takıntı derecesinde bir bağlılık gösterir. Öyle ki Nijad'ın doğumuyla hayata yönelik kötümser bakışı bir tarafa bırakarak iyimserleşir ve üretken bir tavır takınır; bir anlamda hayata sürekli“Nijad merkezli” bakmaya başlar. 1886'da yayımladığı Tefekkür kitabında, bu kötümserlikten iyimserliğe dönüşün izlerine rastlamak mümkündür. Sözgelimi, “Mağmum bir günde” ki “samimi” düşüncelerinin yankısını nakşetmek istediği söz konusu kitabın bir yerinde Ekrem'in, geleceğinden çok umutlu olduğu ve "melek" diye vasıflandırdığı Nijad'ın kendi dünyasına katılmasından duyduğu mutluluğu şu satırlardan kolaylıkla anlayabiliriz:

\footnotetext{
${ }^{1}$ 18. yüzyıl Avrupa'sında gerçekleşen sanat-zanaat ayrımında ölçüt, sanatın salt estetiğe dönük işlevselliği olarak konumlanır. Immanuel Kant, Alexander Baumgarten gibi düşünürlerin estetik kuramlarında sanatın yegâne işlevinin güzellik olarak konumlanışı, bu hususta bir örnek olarak gösterilebilir. İşte modern sanat duyarlılığı da söz konusu konumlanış ekseninde başlar. Bkz. Larry Shiner, Sanatın İcadı: Bir Kültür Tarihi, Çev. İsmail Türkmen, Ayrıntı Yayınları, İstanbul 2013, s. 19-43.

2 Ekrem, yaş konusunda "on beş sene 6 ay" vurgusunu yapar: "Nijad ancak 15 sene altı ay muammer olabildi." (Ekrem 2014: 16b)
} 
"Ne ömür şey bu melek!. Ya Rab, sana nasıl hamd ü senâ edeceğimi bilemem. Bana hayat içinde diğger bir hayat.. cihan içinde diğer bir cihan.. bir cihân-1 feyz-â-feyz bahş ettin!.. Avalime sı̆̆mayan âsâr-1 kudret ve inayetinin bir numune-i letâfeti de bu melek değil mi?. Bu masumun şu mini mini parmakları.. o küçücük elleri bir zaman gelip de memleketinin menfaati için kalem tutacak, vatanının selâmeti için kılıç sallayacak öyle mi?.. Bu ufacık vücut bir vakit gelip de ailesinin saadeti için çalışacak, evlâdının terbiyesi için uğraşacak öyle mi?.. Bu da birtakım vezaifin esiri, bu da bir takım amalin mukayyedi. Hasılı bu da bir adam olacak öyle mi?..."(RME 2014a: 301-302)

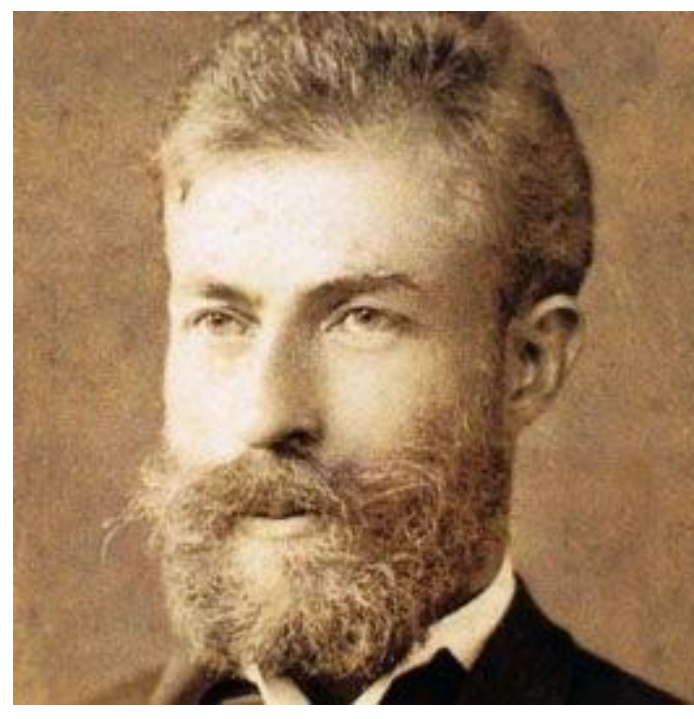

Yine aynı kitaptaki şu satırlarda, çok sevdiği Nijad sayesinde "gülşen-i ümmid"inin "handân" ettiğini dile getirerek, hayatındaki dönüşümün izlerini okurun dikkatine sunar: “Sür şimdi zevkıni şu na'îm-i sabâvetin,/Bak sonra hâline o hıâban-ı behcetin:/Seyr et ne hoş bahardır ol âlem-i sebâb,/Seyr et neş'elerle doğar onda âfitâb,/Seyr et nedir safâ-yı seher feyz-i mâhtâb../Ey gülşen-i ümmîdimi handan eden çocuk!"(RME 2014a: 323)

Peki Ekrem'in Nijad'a yönelik -belki de modern şiirimizde bir ilk olan³, daha sonra Tevfik Fikret'in Haluk tipi ${ }^{4}$ çerçevesinde göreceğimiz- bu yoğun sevginin etkenleri salt bir baba duyarlılığı çerçevesinde açıklanabilir mi? Elbette bu sevgide, söz konusu duyarlılığın yanında başka etkenlerin de söz konusu olduğu düşünülebilir. Bunlar arasında en mühimi, Ekrem'in, kendisi gibi hassas bir sanatkâr olan babası Mehmet Recai Bey'in ölümü sonrası hissettiği yalnızlığı Nijad'la giderme çabasıdır. Ekrem, babası Mehmet Recai Bey'e sağlığında son derece bağlı olmuş; aralarında bir baba-oğul ilişkisi değil, âdeta bir yakın dostluk ilişkisi kurulmuştur. Onun ölümünden sonra ise Ekrem hayat karşısında kötümserleşmiştir. Nijad'ın doğumu, işte bu kötümserleşmeye karşı bir reaksiyon olarak belirmiş gibidir. Bunu, Nijad Ekrem kitabında Nijad'la girdiği bir diyalogdan anlayabilmek mümkün görünmektedir: “Nijad! [...] Mehmet Recai ile yirmi beş yıldan ziyade bir arada bulunduk. Ben ona yalnız muti ve hürmetkâr bir oğul değil idim. O da bana yalnız müşfik, vazîfeperver bir baba değil idi. Biz birbirimizin muhibbi, hem-demi, mahremi idik. Biz

\footnotetext{
${ }^{3}$ Bu ilklik konusunda, Tanzimat döneminin ünlü şairlerinden ve devlet adamlarından Âkif Paşa'nın torunu için yazdığı mersiye akla gelebilir. Fakat söz konusu mersiyenin, dörtlük biçimiyle ve oldukça sade bir dille yazılmasına rağmen tam olarak modern şiir duyarlılığına sahip olduğu düşünülemez; divan edebiyatındaki mersiye geleneği çerçevesinde idrâk edilebilir. Nitekim İbrahim Kavaz, Âkif Paşa'nın şiirlerinde yeniliğe doğru çabaları, modern edebiyat dairesinde yapılan bir atılım değil, modern edebiyata giden yola yapılan birkaç katkı olarak görür. Bkz. İbrahim Kavaz, Belgelerle Âkif Paşa: Hayatı ve Eserleri, Üniversite Kitabevi, Elazı̆̆ 2002, s. 62.

${ }^{4}$ Ekrem'in Nijad'a yönelik yoğun sevgisinin bir benzerini Fikret'le oğlu Halûk arasındaki ilişki çerçevesinde de düşünebiliriz. Fikret, çok sevdiği ve üzerine düştüğü Halûk'u, "Halûk İçin", "Halûk'un Sesi", "Promete" gibi bazı şiirlerinin estetik düzleminde bir merkez olarak konumlandırmıştır. Bkz. Tevfik Fikret, Rübâb-ı Şikeste ve Diğer Eserleri, Haz. Fahri Uzun, İnkılâp Kitabevi, İstanbul 2010, s. 138, 142, 80.
} 
birbirimizi çok severdik. O dünyadan gidince ben pek yalnız kaldım. Hayattan hoşlanmamağa başladım. Sonra Allah seni bana ihsan etti. Sen onun yokluğundan gelen can sıkıntısını bana unutturur gibi oldun. $\mathrm{O}$ bana vaktiyle ne idiyse şimdi ben de sana öyleyim. Ben ona vaktiyle ne idiysem şimdi sen de bana öyle olmalısın değil mi, oğlum?"(RME 2014a: 191)

Ekrem'in ilk çocuğu ve "nazik hayal" (Ekrem 2014a: 224) olarak gördüğü Piraye'nin henüz bir yaşında iken ölmesi; "Nijad'dan aşağı sevmedi[-ğini]" (Ekrem 2014a: 320) belirttiği Emced'in küçük yaşlardan itibaren yatalak hasta olarak kalması da bu bağlamda birer etken olarak düşünülebilir. Yakın bir ilişkide olduğu ve yoğun bir sevgi beslediği babasının ölümü dışında hayatındaki bu üzücü gelişmelerin de Ekrem'de bir boşluk duygusu yarattığını ve Nijad'a son derece yoğun bir sevgi beslemeye yönelttiğini söyleyebiliriz. Nijad'ın 15 yaşında ölümüyle ise Ekrem, o zamana kadar hiç hissetmediği boşluk ve yalnızlık duygusuna düşer. Onun için hayata yeniden iyimser gözlerle bakmak artık mümkün olmaz. Talim-i Edebiyat'ın yazımına devam etmek veya Meşrutiyet yıllarındaki çeşitli görevlerde bulunmak (Parlatır 2012: 18-19) dahi onun oyalanmasına yeterli gelmez. Artık Ekrem için sürekli bir matem hayatı söz konusudur; hatta dostları Tevfik Fikret ve Hâlid Ziya dahi zaman zaman bu matem hayatına ortak olur. Nijad'ın ölümü sonrası ziyaret ettikleri Ekrem ile olan bir anekdot bu hususta önemli bir örnek değeri kazanır:

“Geçenlerde Tevfik Fikret'le Halit Ziya Bey gelmişlerdi. Ben Nijad'ın bazı metrukât-ı kalemiyyesini karıştırıp yine muttasıl ağlıyordum. Beni bu halde gören bu iki muhibb-i vefâkârım kim bilir ne derece müteessir oldular ki onlar da, belki arzuları hilâfına, bilâ-ihtiyâr girye-rîz olmağa başladılar. $O$ zaman, yüreğimin üzerinde dağlar kadar sıklet-bahş olan bâr-1 azîm-i felâket birden bire ber-taraf oluyormuş gibi bir hâl-i hiffet hissettim. Ben yine ağlıyordum ama artık o ağlayış acı değil bilâkis pek tatlı, pek rûh-perver idi."(RME 2014a: 225)

İşte Ekrem'in Nijad'la -yukarıda kısaca özetlediğimiz- ilişkisi, Ekrem'in sanat hayatını doğrudan etkiler. Nitekim Nijad'ın doğumunun sevinciyle kaleme aldığı, belki de heyecanını ve acısını samimiyetle yazmasından ötürü düzensiz bir şekilde ortaya çıkardığg ${ }^{5}$ Tefekkür ve ölümünün hüznüyle ortaya çıkardığı Nijad Ekrem adlı kitaplarında odak nokta Nijad'ın bizzat kendisidir. Fakat belirtmek gerekir ki Nijad'ın tipolojisi Tefekkür'de pek belirsiz kalır; söz konusu tipoloji birtakım sevgi ve bağlılık ifadeleri ile somutlaşmaktan öteye geçmez. Nijad'ın asıl tipolojisini Nijad Ekrem'de buluruz; bu eserde Nijad hemen hemen her yönüyle resmedilir ve onun adeta tipolojik bir haritası ortaya çıkarılır. Bu çalışmada amacımız söz konusu iki eser dâhilinde fakat daha çok Nijad Ekrem temelinde Nijad'ın tipolojisindeki temel özellikleri saptamak ve böylelikle onun Ekrem tarafından nasıl

\footnotetext{
5 Burada “düzensizlik" ifadesini, plansızlık bağlamında kullanmaktayız. Ekrem'in söz konusu iki kitabı, biçimsellik/kompozisyon açısından plansız bir görünüm arz eder.
} 
bir tip çerçevesinde estetik düzleme dâhil edildiğini ortaya koymaktır. Eklemek gerekir ki, Tefekkür ve Nijad Ekrem'deki estetik düzlem, salt nazım şeklinde değil, aynı zamanda yer yer nesir biçimindedir. Fakat söz konusu nesri, Ekrem'in ilk olarak "nesr-i muhayyel" (RME 2014b: 39) olarak isimlendirdiği, fakat sonrasında Halid Ziya'nın "mensur şiir" tabirini uygun gördüğü (RME 2014b: 211) bir tarzda, yani "serbestâne tasvîr-i efkâr ü hissiyata müsait olan" (RME 2014b: 46) bir şekil içerisinde değerlendirebiliriz. Bunların her birinde şairane hisler ve şiire özgü armonik unsurlar somutlaşma zemini bulur. Dolayısıyla Nijad tipolojisinin izsürümünde bulunulurken, bu nesirler de dikkate alınacaktır.

\section{OLAĞANÜSTÜ BİR ÇOCUK PORTRESİ: NİJAD}

Nijad tipolojisi üzerine ilk olarak belirtmemiz gereken, söz konusu tipolojinin olağanüstü bir mükemmeliyet çerçevesinde somutlaştığıdır. Nijad, Ekrem nazarında şahsında bütün iyi özellikleri toplayan, yaşından büyük marifetler sergileyen bir çocuk olarak görülür ve o şekilde estetik düzleme dâhil edilir. Şüphesiz böyle bir dâhil ediliş, yer yer, geleneksel dinî/tarihî kişilik anlatılarındaki olağanüstülükleri veya geçmişten günümüze sanatçı biyografilerinin yazımında -Ernst Kris ve Otto Kurz tarafından tespit edilen- belli motifler eksenindeki mükemmelleştirme çabalarını (Kris-Kurz 2016: 9-20) anımsatmaktadır. Gerçi Nijad ne bir tarihî/dinî kişilik ne de -piyano çalmasına ve bazı şiirler kaleme almış olmasına rağmen- bir sanatçı olarak görülebilir; nitekim Ekrem de esas olarak onu böyle sıfatlar ekseninde tasvir etmeyi amaçlamaz. Fakat yine de Ekrem'in biyografik kurgulamasında, tıpkı dinî/tarihî kişilik veya sanatçı biyografilerine dönük kurgulamalardaki gibi zaman zaman olağandışılık sınırına yaklaşan olumlu özellikler temeldir. Bu olumlu özelliklerden en çok göze çarpanı, şüphesiz, Nijad Ekrem'deki “Bir Cevap ki Kitap Olmalı İdi!” başlıklı yazısındaki satırlarda açığa çıkar; bu satırlarda, Nijad’ın beş yaşına kadar "biraz" çocukluk edişi fakat ilerleyen yaşlarda "dünyayı, hayatı tamamıyla anlamış" ve adeta bir büyük düşünür olarak algılayışı konu edilir. Kaynağını antik dönem mitlerinden alan aziz ve sanatçı anlatılarındaki vaktinden evvel büyüme/erken yaşta büyük gelişim gösterme motifinin (Kris-Kurz 2016: 34-45) bir benzeri de işte bu noktada belirir: "Nijad hiç çocuk olmadı diyemem: Beş yaşına kadar biraz çocukluk etti. Sekiz yaşına kadar temkinli bir genç oldu. On iki yaşında dünyayı, hayatı tamamıla anlamış, muhite göre bir hüner ve faziletten behredâr bir âk1l-1 kâmil idi."(RME 2014a: 224)

Yine aynı kitapta Nijad'a hitaben kaleme aldığı "Son Söz: Hep ve Hiç!” şiirinde bu husus bir kez daha açığa çıkar.

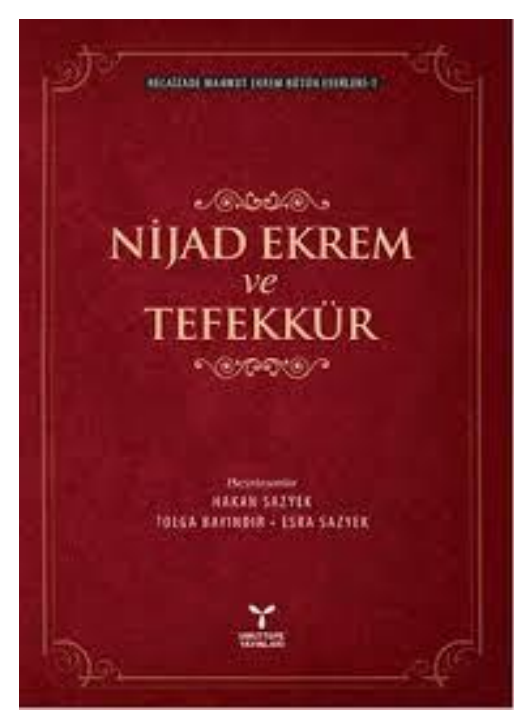


Nijad, henüz çocuk yaşlarda hayatın anlamını kavramış, onun gözyaşı dahi bir "pür-felsefe bir şi'r" hâline gelmiştir: "Pür-felsefe bir şi'r idi giryende hayâtın; / Mâhiyyeti pek belli idi sende hayatın."(RME 2014a: 230)

Fakat bu erken gelişmeyi erken ihtiyarlayış takip eder; Ekrem, Nijad için bu hususta "on beş yaşına vasıl olunca sanki ihtiyarladı" (RME 2014a: 224) ifadesini kullanır.

Nijad'ın tipolojisine dönük kurgulaştırmada ortaya konulan ve dikkat çeken bir başka özelliği, onun millı̂ duyarlılığının yüksek bir mertebede olmasıdır. Bu durum en çok Nijad Ekrem'deki “Galeyân-ı Hamiyyet” başlıklı yazıda açığa çıkar. Burada Ekrem, Nijad'ın oldukça vatansever olduğunu, Türklüğünü iftiharla karşıladığını, nitekim bu duyarlılığından ötürü "tarihi, coğrafyayı hâl-i hâzırında ulûm-ı sâirenin hepsinden ziyade sev[-diğini]” (RME 2014a: 77) dile getirir ve hemen ardından bu yüksek millî duyarlılı̆̆ın somutlaşmasına örnek olarak Nijad'la Taksim'deki Topçu Kışlası'nın önünden geçtikleri sırada rast geldikleri manzara karşısındaki izlenimlerini nakleder. Kışlanın önünden askerlerin tantanalı geçişi karşısında baba-oğul oldukça duygulanmıştır; fakat özellikle Nijad'ın bu esnadaki tutumu daha çarpıcıdır. O, bu sahne sırasında gözyaşlarına hâkim olamaz. İşte Ekrem bu gözyaşlarını onun "mübarek" ve yüce vatan sevgisinin bir delili olarak görür: “Onun gözlerinden yaşlar dökülüyor, meğer o ağlıyormuş! Bu ağlayışın ne mübarek, ne âlî bir hiss-i necîb-i vatan-perverî ilcasıyla vuku bulduğunu anlamak muhtâc-1 teemmül değildi. 'Aferin Nijad! - dedim - berhudar ol.. Allah seni vatana bağışlasın!'”(RME 2014a: 78)

Fakat Ekrem, bu esnada Nijad'ın sadece vatanseverliğinin ne kadar yüksek bir mertebede oluşunun somut göstergesine değil, aynı zamanda söz konusu sahne ile daha da yükselen vatanseverliğin onda ne gibi bir gelecek tasavvuru doğurduğuna şahit olur; şu cümleleri duyar Nijad'ın ağzından: “Baba! Ben asker olacak değil idim. Fakat bugün fikrim bütün bütün değişti. Ben askerden başka kat'iyen hiçbir şey olmayacağım. Lâzım gelince ben de bunlar gibi bu vatan için öleceğim. Rica ederim, beni askere verin."(RME 2014a: 78)

Öte yandan, aynı yazıdan hemen sonra gelen ve "Nijad'a" başlığını taşıyan şiirde de Nijad'ın yüksek vatanseverlik duygusunun Ekrem tarafından alımlanış biçimine şahit olabiliriz. Bu şiirde Ekrem, adeta "Galeyân-1 Hamiyyet"in şiirsel bir yeniden-yazımına yönelir. Nijad'ın Türklüğüyle övünüşü, milli duyarlılığının son derece yüksek oluşu burada şiirsel bir tasvir imkânına kavuşur: Söz konusu şiirdeki "Fikr-i hamiyete müteşahhas misâl idin,/Kalbinde çoktu millet için gayretin senin" ile "'Türküm!' deyip onunla mübâhât eder idin,/Unvân-1 fahr idi sana milliyetin senin"(RME 2014a: 79) beyitleri bu bağlamda düşünülebilir.

Ekrem'in tipolojisinde Nijad'1 sadece milli duyarlılığ görmeyiz; o, aynı zamanda, ahlâki duyarlılığı da ileri boyutta bir tip olarak belirir. Ekrem, 
Nijad Ekrem'deki "Esâs-1 Ahlâk Yaradılıştır" başlıklı yazısında, İstinye'de yaptığı gezinti sırasında verdiği ahlâkî telkinleri Nijad'ın dinlemekten geri durmadığını dile getirir ve ahlâk konusunda son derece duyarlı olduğunun altını çizer. Fakat bu yüksek ahlâki duyarlılıkta en büyük etken, söz konusu telkinler değildir; Ekrem'e göre bu çerçevede yaradılışı düşünmek gerekir; nitekim yazının başlığından anlaşılacağı gibi Ekrem, ahlâkın esasen bir yaradılış özelliği olduğunu düşünür. Bu, Nijad için de geçerlidir:

“İtiraf etmeliyim ki ta küçük yaşından beri nezâhet-i etvâr u mu'âmelâtıyla herkesi kendisine mecbur-ı hürmet eden bu nâdire-i fıtratın fezâil-i ahlâkıyyesine benim muavenetim olduysa bile pek cüz'îdir. Evet, Nijad'ın kava'id-i metîne-i ahlâkıyyesi de sair her türlü meziyyât-1 zâtıyyesi gibi kendisiyle beraber doğmuştu."(RME 2014a: 105)

Nijad'ın yüksek ahlâki duyarlılığındaki yaradılış eksenine vurgu yaptıktan sonra Ekrem, onun söz konusu duyarlılığının tavır ve konuşmalardaki yansısını örneklemeye çalışır. Bu örneklemeler, yalan ve kötü söz söylememek, herkese hürmet göstermek, misafire saygıda kusur etmemek gibi hususiyetler etrafında toplanır:

“Nijad müddet'ül-ömr bir kere olsun yanılıp da yalan söylememiş idi ki yalancılığın insanlığa ne kadar zül getirecek sıfât-ı zemîmeden olduğunu kendisine anlatmağa lüzum göreyim.

"Nijad'dan hiçbir zaman müstehcen bir söz veya şütum nev'inden galiz bir tabir işitilmemiş idi ki bundan dolayı kendisini muahezeye mecbur olayım.

Nijad'ın tanıdığı veya tanımadığı bir kimseye ve hatta evimizin uşaklarına, hizmetçilerine karşı hürmet ve nezakete mugayir bir muamelesi vaki olmamış idi ki bu hâlin muvafık-ı edeb ü terbiye olmayacağını kendisine ihtar edeyim.

Nijad geceliğiyle bir misafirin huzuruna çıkmak şöyle dursun gayet lâubali olduğumuz halde hatta benim yanıma bile bir defa olsun gelmemiş idi ki bunun çirkinliğinden bahsetmiş olayım." (RME 2014a: 106)

Yine Nijad Ekrem'deki "Bir Cevap ki Kitap Olmalıydı!” başlıklı yazısında Ekrem, Nijad'ın adeta bir "mesih" gibi portresini çizerken, onun yüksek ahlâki duyarlılığını yeniden özetler; böylelikle bu özetlemede Nijad'ın diğer ahlâki vasıflarını da öğrenmiş oluruz. Bunlar; "kanaatkâr"lık, "âşık-1 fazîlet"lik, "şâyeste-i mahremiyyet"liktir (RME 2014a: 224). Bütün bu ifadelerden anlayabiliriz ki Nijad, bir ahlâk timsâli olarak tipolojik kurgulamaya dâhil edilir; böylelikle onun ulvî tarafı vatanseverliğin yanında ahlâkîliği de içermiş olur.

Nijad'ın tipolojisinde öne çıkan bir diğer mühim hususiyet ise büyük ölçüde yetenekli oluş noktasında dügüumlenir. Nijad, küçüklüğünden itibaren derslerini hızlı bir şekilde öğrenmeye meyyaldir. Fransızcaya da erken yaşlarda ve oldukça iyi bir şekilde hâkim olmaya başlar; öyle ki zaman zaman babasıyla Fransızca konuşur. İşte bu yeteneklerinden ötürü Ekrem, Nijad'a hediye ettiği kitaplardan birinin ardına -ona hitaben- şunları not 
'Vücûdunuzla vücudum değil midir şâhid?

Nedir hayât? Acı bir şey.. Bütün azâb, elem..

Memâtise ebedi ruhun istirahatidir.

Ölüm.. Evet! O da fânilerin felâketidir..

Fakat bütün bu felâket, bu hasret ü mâtem

Gidenlere değil, ancak kalanlara â'id.."(RME 2014a: 51)

Bu hassaslık esasen Nijad’ın ilk yıllarında dahi görülür. Tefekkür'deki “Bir Manzarâ-i Ulviyye" başlıklı yazısına eklediği şiirin bir beytinde Ekrem, onun henüz üç buçuk yaşında bazı vaziyetlerinin hüzünle somutluk kazandığını ve bir "garâbetiityân" ettiğini dile getirir: “Gâhî nedir o hâl-i hazîn-i teessürün?/Her vaz'ı bir garabeti ityân eden çocuk!” (RME 2014a: 322)Yine Nijad Ekrem'deki “Mevt.. Nijad” başlıklı şiirin sonuna eklenen yazıdan anlaşıldığı üzere, Ekrem'e göre Nijad'ı ölüme götüren bir sebep de ondaki bu hassaslık ve maraziliktir ki bunlardan ötürü "shhhate daima lâkayd bulunur" (RME 2014a: 51) ve hayata bağlılık noktasında bir kopukluk durumu yaşar.

Nijad tipolojisindeki mükemmeliyeti ihlâl eden bir diğer önemli hususiyet de dil bilinci noktasında düğümlenir. Nijad, kardeşi Ercümend ile birlikte okuduğu Frere Mektebi'nde son derece yetkin bir Fransızca eğitim almıştır; üstelik, yukarıda da belirttiğimiz gibi, Nijad yetenekli yaradılışı sayesinde Fransızcayı hızlı öğrenir ve hatta zaman zaman babasıyla Fransızca konuşabilecek kadar ona hâkim olur. Fakat Türkçe konusunda aynı durum görülmez; hatta Türkçesi Fransızcası yanında sönük kalır. Bu durumu, Ekrem'in kendisine yolladığı bir mektubundaki şu uyarısından anlarız:

"Fransızca tahsilini hocaların takdir ediyorlar. Fakat Türkçeni beğenmiyorum.

Oğlum, yalnız Fransızca ile kendine bir mevkı'-i mümtâz temin edemezsin.

Türkçeni de Fransızcan derecesine getirmeli ve belki de ondan daha ileriye götürmelisin. Bu maksad-1 mühimde sana şevk-1 mukaddem olacak şey de

(Ekremzade)liğini hiçbir vakitte aklından çıarmamaktır."(RME 2014a: 110-111)

1312 tarihini taşıyan bu mektuptaki uyarıyı Nijad göz önünde bulundurup da Türkçesini Fransızca derecesine getirmiş midir, bilinmez; fakat son tahlilde Nijad tipolojisinde bu olumsuzluk başlı başına yer almaktadır.

Nijad, gerek maraziliğinden gerekse de Türkçe bilincinin eksikliğinden muaf olamasa da genel itibariyle ve yukarıda da belirttiğimiz gibi sanatçı ve aziz biyografilerini andırırcasına mükemmeliyete dönük bir tipolojik kurgu içerisinde Ekrem'in eserlerinde yer almaktadır. Tam bu noktada iki husus üzerinde durmak gerekir. İlk olarak, Nijad'ın tipolojik kurgulanışında Ekrem tek fail değildir; Ekrem'in etrafında bulunan ve Nijad'ı sevdiği bilinen bazı şair ve yazarlar da söz konusu kurgulanışa katkı sağlar; en azından Nijad tipolojisini yer yer yeniden-üretir. Sözgelimi, Ekrem'in kurucu bir fonksiyon üstlendiği Servet-i Fünun 
hareketinin öncü isimlerinden Tevfik Fikret ve Hâlid Ziya'nın Nijad Ekrem'in sonunda yer alan yazılarında, Nijad'ın Ekrem tarafından çizilen tipolojisiyle örtüşen noktalar vardır. Fikret, Nijad'ı tıpkı Ekrem gibi "görenleri hayran eden [...] zekâ-yı müfrit, [...] istidâd-ı hârık" (RME 2014a: 239) olarak çizer, onun "hiçbir zaman çocuk olma[-dığını]" hatta "küçüklügünden beri büyük bir adam" (RME 2014a: 240) gibi göründüğünü dile getirir. Hâlid Ziya ise Nijad'ın evraklarındaki şiirlere değinerek Nijad'ın sanatçı duyarlılığı yönünü yeniden ve daha net bir şekilde tasvir eder; onun hem Fransızca hem de Türkçe kaleme aldığı şiirlerinden çeşitli örnekler verir. İkinci olarak ise Nijad'ın tipolojisindeki olağanüstü görünümün gerçeklikle ilişkisi hususunda okur yer yer şüpheye düşebilir. Nijad gerçek hayatta da esasen böyle bir tipolojiye sahip olabilir mi? Nijad, hakikaten de olağan hayatın akışı içerisinde bize "olağanüstü" gelen bir hayat mı sürmüştür? Nijad'ın hayatı üzerine Ekrem ve bazı dostlarının yazdıkları dışında herhangi bir belge olmadığı için bu soruya kesin bir biçimde olumlu veya olumsuz cevap vermek mümkün değildir; dolayısıyla söz konusu tipolojinin alımlanışı, zaman zaman -Tzvetan Todorov'un ünlü fantastik kuramındaki karşıtlıktan (opposition) hareketle ifade edersek- olağanüstü ve tekinsiz arasındaki ${ }^{6}$ çizginin ortasında konumlanacağı tahmin edilebilir. Hâliyle okurların, Nijad'ın tipolojisini alımlarken, ara ara da olsa, Ekrem'in -ve dostlarının- yoğun sevgisinin bir ürünü olarak idealize edilmiş büyük bir aziz veya usta bir sanatçı karşısında mı yoksa gerçek kurgusu hayattaki karakteriyle birebir örtüşen, üstün yetenekli ve duyarlı bir çocuk karşısında mı bulunduğu konusunda bir tereddüt yaşayacağını düşünmemek olası değildir.

\section{SONUÇ}

Tanzimat edebiyatının öncü şairlerinden ve yazarlarından olmakla birlikte daha çok kuramcı yönüyle öne çıkan ve kendinden sonraki kuşaklar nezdinde "üstad" olarak kabul edilen Recaizade Mahmut Ekrem'in eserlerinde en çok ele alınan tip, 15 yaşında vefat eden oğlu Nijad'dır. Bu hususta 1886'da yayımlanan Tefekkür ve özellikle de 1910'da yayımlanan Nijad Ekrem adlı eser büyük önem arz etmektedir.

Gerek Tefekkür'de gerekse Nijad Ekrem'de Nijad tipolojisi, hem manzum hem de mensur olarak, tıpkı dinî/tarihî kişiliklerin veya büyük sanatçıların biyografilerinde gördügümüz mükemmelleştirmeye dönük bir kurgulanış biçimiyle ortaya çıkar; dolayısıyla Nijad, bazı istiSnalarla birlikte, oldukça idealize edilmiş, olağanüstülük sınırlarına yaklaşmış bir figür olarak belirir: Erken yaşta adeta bir filozoftur; millî ve ahlâkî duyguları son derece kuvvetlidir; yer yer sanatçı duyarlılığına sahiptir; tabiata ve hayvanlara büyük bir sevgi

\footnotetext{
${ }^{6}$ Todorov, alımlanma sırasında okurun olağandışı (olağanüstü) ve olağan (tekinsiz) arasında yaşadığı tereddüdü, fantastiğin en önemli özelliğinin, Bkz. Tzvetan Todorov, Fantastik: Edebi Türe Yapısal Bir Yaklaşım, Çev. Nedret Öztokat, Metis Yayınları, İstanbul 2012, s. 30-31.
} 
besler; korkusuzdur vs. Okuru alımlanış sırasında olağanüstülük ve tekinsizlik arasında bırakabilecek olan böyle bir kurgulanış biçiminde, elbette tek fail Ekrem değildir; Tevfik Fikret ve Hâlid Ziya gibi Ekrem'i "üstad” olarak vasıflandıranlar da Nijad hususunda kaleme aldıklarıyla söz konusu tipolojiye yer yer katkı sunmuşlardır.

\section{KAYNAKÇA}

Kavaz, İbrahim (2002). Belgelerle Âkif Paşa: Hayatı ve Eserleri, Elazığ: Üniversite Kitabevi.

Kris, Ernest-Kurz Otto (2016). Sanatçı İmgesinin Oluşumu: Efsane, Mit ve Büyü. Sabri Gürses (Çev.), İstanbul: İthaki Yayınları.

Parlatır, İsmail (2012). Recâ̂-zade Mahmut Ekrem. Ankara: Akçağ Yayınları

Recaizade Mahmut Ekrem (2014a). Bütün Eserleri 1: Nijad Ekrem-Tefekkür. Hakan Sazyek vd. (Haz.), Kocaeli: Umuttepe Yayınları.

Recaizade Mahmut Ekrem (2014b). Bütün Eserleri 2: Takdîr-i Elhân-Kudemadan Birkaç ŞairPejmürde-Takrizat. Hakan Sazyek vd (Haz.), Kocaeli: Umuttepe Yayınları.

Shiner, Larry (2013). Sanatın İcadı: Bir Kültür Tarihi. İsmail Türkmen (Çev.), İstanbul: Ayrıntı Yayınları.

Tanpınar, Ahmet Hamdi (2007). XIX. Asır Türk Edebiyatı Tarihi. Abdullah Uçman (Haz.), İstanbul: Yapı Kredi Yayınları.

Tevfik Fikret (2010). Rübâb-ı Şikeste ve Diğer Eserleri. Fahri Uzun (Haz.), İstanbul: İnkılâp Kitabevi.

Todorov, Tzvetan (2012). Fantastik: Edebî Türe Yapısal Bir Yaklaşım. Nedret Öztokat (Çev.), İstanbul: Metis Yayınları. 